Received $5^{\text {th }}$ Maret 2020 Accepted $6^{\text {th }}$ August 2020

Link to DOI:

10.25220/WNJ.V04.i1.0004

Journal Website: www.worldnutrijournal.org

\section{Correlation between intensive phase treatment of antituberculosis drugs with nutritional status of patients with tuberculosis in Kupang city}

\author{
William Lie ${ }^{1}$, Ika Febianti Buntoro ${ }^{2}$, Rahel Rara Woda ${ }^{3}$, Christina Olly Lada ${ }^{3}$ \\ 1. Faculty of Medicine, Nusa Cendana University, Kupang, East Nusa Tenggara, Indonesia \\ 2. Department of Tropical Medicine, Faculty of Medicine, Nusa Cendana University, Kupang, East \\ Nusa Tenggara, Indonesia \\ 3. Department of Nutrition, Faculty of Medicine, Nusa Cendana University, Kupang, East Nusa \\ Tenggara, Indonesia
}

\begin{abstract}
Background: Indonesia is a country with the third highest tuberculosis incident in the world. Nutritional status is very important to patients with tuberculosis, an optimal nutritional status created an optimal immune system. Lack of adequate nutritional intake, prolonged the antituberculosis drug treatment and caused them to get a slower recovery. Therefore, the writer found the need of knowing the relation of intensive phase treatment of anti-tuberculosis drugs with nutritional status of patients with tuberculosis in Kupang City.

Objectives: To know the relation between intensive phase treatment of anti tuberculosis drugs with nutritional status of patients with tuberculosis in Kupang City.

Methods: This study was an observational analytic study with a nested cohort design conducted by 11 public health centers in Kupang City by taking secondary data from medical records. The sampling technique used consecutive sampling with 84 respondents who met the inclusion and exclusion criteria. The study was analyzed univariately, and bivariately using Mc Nemar.

Results: From 84 respondents, before intensive phase tuberculosis treatment 61 respondents (72.6\%) had abnormal nutrition status, and 23 respondents (27.4\%) had normal nutritional status, while after intensive phase tuberculosis treatment from 84 respondents it was found that 50 respondents (59.5\%) had abnormal nutrition status, and 34 respondents $(40.5 \%)$ had normal nutritional status. The result of the bivariate analysis test shows a significant different in nutritional status before and after tuberculosis treatment with $\mathrm{p}$ value $=0.001$.

Conclusions: There was a significant different in nutritional status before and after tuberculosis treatment indicating that anti-tuberculosis drug treatment can affect the nutritional status of patients with tuberculosis.
\end{abstract}

Keywords anti tuberculosis drugs, nutritional status, Kupang city

\section{Corresponding author:}

William Lie, $M D$

Faculty of Medicine, Nusa Cendana University, Kupang, East Nusa Tenggara, Indonesia Email:williamlie75@gmail.com

\section{Introduction}

Tuberculosis (TB) is one of the deadly communicable diseases and is now become a concern of the public worldwide. ${ }^{1} \mathrm{~TB}$ is currently become one of the world's health problems. ${ }^{2}$ There 
are differences in epidemiology of TB between developing countries and industrial countries. In countries with low living standard and poor health resources, the risk of new TB infection happens at productive age (15-59 years old) is $80 \%$. In developed countries where TB incidence has decreased, the majority of TB cases arise as a result of endogenous reactivation of TB. This cause the highest rate of disease to occur in elderly ( $>65$ years old). ${ }^{3}$

In 1995 the World Health Organization (WHO) recommended a Directly Observed Treatment Short Course (DOTS) as a strategy to control TB in the world. The World Bank declared the DOTS strategy as one of the most cost-effective health interventions, integration into basic health services is highly recommended for efficiency and effectiveness. ${ }^{4}$ Based on data from around the world, TB is one of the 10 leading causes of death. In 2017, TB caused an estimated 1.7 million deaths. Based on data from WHO, TB is present in all countries and all age groups. Globally, TB sufferers are estimated to have as many as 10.0 million people and in 2017 there are 5.8 million men, 3.2 million women and 1.0 million children affected with TB. ${ }^{5}$

TB consist of 2 phases of treatment which is intensive phase for 2 months and continuous phase for 4-6 months. There is a difference between intensive phase treatment and continuous phase treatment, where the intensive phase uses 4 kinds of drugs and the continuous phase uses only 2 kinds of drugs. ${ }^{6,7}$ Therefore based on this background we wanted to conduct a research on the relation between intensive phase treatment of anti tuberculosis drugs with nutritional status of patients with tuberculosis in Kupang City.

\section{Methods}

This research was conducted in 11 Public Health Centers around Kupang City, East Nusa Tenggara, Indonesia from June to September 2019. This research is an observational analytical research that examined the relation between each variables. This research aimed to determine the relation between intensive phase treatment of anti tuberculosis drugs with nutritional status of patients with tuberculosis in Kupang City.
This research used the nested cohort method design, which emphasized on time and independent and dependent variables only once at a time. The sampling technique used consecutive sampling with the total 84 respondents who met the inclusion and exclusion criteria. This research was then analyzed univariately and bivariately using Mc Nemar test.The independent variable in this research is intensive phase tuberculosis treatment, and the dependent variable is the nutritional status in patients with tuberculosis.

\section{Results}

Table 1. shows the baseline characteristic data of patients with tuberculosis at Public Health Centers around Kupang city, the highest number of respondents was located at Oesapa Public Health Center with the total number of 40 people $(47.6 \%)$ and the lowest was located at Kupang Kota Public Health Center with the total number of 0 people ( $0 \%$ ). Respondents were divided into age groups according to the 2009 Indonesian Ministry of Health, consist of late adolescence (17-25 years), early adulthood (26-35 years), late adulthood (36-45 years), early elderly (46-55 years), late elderly (5665 years) and over elderly ( $>65$ years). Based on the data above, the highest age group who suffer pulmonary tuberculosis is the early adult group $(25.0 \%)$, followed by the late adolescent $(21.4 \%)$ and late adulthood (17.8\%) which is the productive age. The results also showed that the total number of respondents in this research were 84 respondents, consist of 51 male $(60.7 \%)$ and 33 female $(39.3 \%)$. Among 84 subjects, 57 respondents (67.85\%) had sputum Ziehl-Neelsen staining procedure positive for acid-fast bacilli (AFB).

As shown in Table 2, 23 people had normal nutritional status before the intensive phase treatment $(27.4 \%)$, and 61 people had abnormal nutritional status $(72.6 \%)$. After the treatment, 34 people had normal nutritional status $(40.5 \%)$, and 50 people had an abnormal nutritional status (59.5\%).

Based on statistical analysis using Mc Nemar test, the results showed a significant level of $p$ value $=0.001(p<0.05)$ which indicated that there was a significant change in patient nutritional status after the intensive phase treatment of anti tuberculosis drugs $(\mathrm{p}=0.001$ or $\mathrm{p}<0.05)($ Table 3$)$. 


\section{Discussion}

According to geographical location the research took place around Kupang City, one of the influence factors of TB transmission is temperature, Kupang City has an average temperature of $31^{\circ} \mathrm{C}$ that is above the standard set by the Indonesian Ministry of Health Regulation No.1077/Menkes/Per/V/2011 that mentioned about the temperature requirement should be at around $18-30^{\circ} \mathrm{C}$. The presence of Mycobacterium tuberculosis at an inappropriate temperature has the potential to increase the favorable conditions for bacteria to live and multiply and potentially increasing the transmission of tuberculosis as well. ${ }^{8,9}$

Population density in Kupang city is around 2,289.39 people $/ \mathrm{km}^{2}$ that apparently does not meet the requirement of an ideal population density that supposed to be $<9 \mathrm{~m}$ per person, this condition cause new TB cases that occurs due to the increased population density, it resulted in the increasing of TB incidence as well. This is in line with the research conducted by Jimmy Lahabama $^{9}$ in 2013 in Pontianak Indonesia stating that if the density does not meet the requirements then the incidence of TB will be higher in areas with high population, therefore there will be more people affected by TB compared to areas that meet population density requirements.

Nutritional status is one of the most important factor in the body's defense against infection. It has been proven that nutritional deficiencies are associated with impaired immune function. In poor nutritional conditions, the body's immune response will be weakened so that the ability to defend against infection will be decreased. ${ }^{2}$ Malnutrition of protein energy and micronutrient deficiency can cause secondary immunodeficiency which increases one's vulnerability to tuberculosis infection. ${ }^{10}$

TB infection increase energy needs at rest called resting energy expenditure (REE) at around 10-30\% of the energy needs of normal people. The process of how the infection could affect nutritional status in person with tuberculosis started with an increasing of leptin resulting in a decreased of nutrient intake and malabsorption, while in the process of infection there is an increase in energy needs by the body and there is also an increasing of IL- $1 \beta$, IL- 6 , TNF- $\alpha$ and malondialdehyde (MDA) as a response of inflammatory process. The inflammatory process will activate the proteolysis pathway of the ATPdependent ubiquitin intracellular protease and subsequently the protein is destroyed in proteasomes and regulated by TNF- $\alpha$. The increased production of IFN-IL, IL-6, TNF- $\alpha$ due to TB infection inhibits the activity of the lipoprotein lipase (LPL) in fat tissue. LPL plays a role in the process of triglycerides cleansing. The increasing of LPL will then increase the process of triglycerides cleansing, decrease the synthesis of fatty acid, and increase the lipolysis process of fat tissue, the decreasing of fatty acids synthesis will lower the body weight and nutritional status. ${ }^{10,11}$

From the results of the study it was found that TB cases are most common in 26-35 years age group with the total of 21 respondents $(25 \%)$ that are included in the productive age group, this is because those in productive age group are often exposed in a crowd and populous working environment that allow them to contact with many other people, this can increase the risk of TB. Such working conditions make it easier for someone of productive age to get infected by TB. ${ }^{12}$

From the results of the study it was found that respondents with new TB cases were low occurred in the elderly age group above 65 years by only 4 people $(4.8 \%)$ because in the elderly age group there will be a degradation in physiological function of the body, a decrease in body muscle mass and a decrease in appetite, however to get an optimal immune system the nutritional status and nutritional intake must also be optimal, the infection process require a good nutritional status and nutritional intake to help optimizing the immune system in the body to eliminate TB bacterias. TB infection can increase energy needs to maintain the body's immune system in running the system energy use.$^{13}$

From the results of the study it was found that most respondents who are involved in the study were male with the total of 55 respondents $(60.7 \%)$ and there are only 31 female respondents $(39.3 \%)$. Gender is also one of the risk factors of TB, where men has a higher risk than women especially in cases of pulmonary TB because men have high mobility and are often engaged in activities outside of the home so that the possibility of exposure to Mycobacterium tuberculosis is higher. In addition, men also prone to bad lifestyle habits such as 
smoking and drinking which lower the performance of immune system that later make them more vulnerable to tuberculosis infection, but an increase in nutritional status is faster in men than women, this is according to research conducted by Lestari ${ }^{14}$ in 2016 in the Lung Hospital of West Java Province involving 62 respondents stating that after TB treatment the increasing of BMI is higher in men than women, and because of how the immune system is closely related to nutritional status, therefore according to this research the successful treatment will likely higher to happen in men than women. ${ }^{14}$

Poor nutritional status will lower patients' immune system that can cause an escalation in the number of TB bacteria inside the body. The result of AFB examination in the majority of this case will likely be positive and with the prognosis of TB that has been given an anti-tuberculosis drugs there will be a conversion of AFB positive to negative, AFB conversion is influenced by nutrient intake, if nutrient intake decreased it will result in calorie and protein deficiency. Lack of protein will cause atrophy and reduce thymus cell proliferation which later resulted in the decreasing number of $T$ lymphocyte cells production. $\mathrm{T}$ lymphocytes play a role in activating macrophages to destroy $\mathrm{TB}$ bacteria. If there is a decrease in the number of $\mathrm{T}$ lymphocytes, this will cause the body's defense system to weakened, macrophages are no longer able to digest TB bacteria, therefore these bacterias will stay in the lung tissue, delaying the sputum conversion and prolong the healing process. ${ }^{15}$

Based on the results of the study it was found that there was an increase in the body weight but there was no improvement in nutritional status after an intensive phase treatment, this is in line with the research by Priyatomo et $\mathrm{al}^{6}$ in 2014 conducted on 30 people in Indonesia at the Lung Diseases Health Unit in Health Center Pontianak, it was found that there was a difference between the nutritional status in the intensive phase treatment of 2 months and 6 months, in 2 months of the intensive phase treatment the research found that there was an increase in body weight but there was no improvement in nutritional status, while in the 6 months of continuous phase treatment there was an increase in body weight and accompanied by a significant increase in nutritional status.
Based on the results of the analysis it was found that there was a significant change in patient nutritional status after the intensive phase treatment of anti tuberculosis drugs with $p$ value of $<0.001$ $(p<0.05)$ so the hypothesis of $\mathrm{H}_{0}$ is rejected while $\mathrm{H}_{1}$ can be accepted, and it was approved that there was a relation between intensive phase treatment of anti tuberculosis drugs with nutritional status of patients with tuberculosis in Kupang City.

This is in line with the research conducted by Huda et al in 2015 with the title Differences in Body Mass Index Before And After Treatment in Pulmonary Tuberculosis Patients at the Central Institute of Lung Health in Surakarta where this study was conducted on 216 respondents in Indonesia at The Lung Health Center in Surakarta by looking at the average differences between nutritional status before and after being treated with TB intensive phase treatment with $p$ value $<0.001$ ( $p$ $<0.05)^{7}$, research from Rohini et al in 2013 on 40 respondents conducted in The Institute of Thoracic Medicine in India using a retrospective study showed that there were significant changes in nutritional status before and after intensive phase treatment under the DOTS program, with proper food choices that is suitable for the patient's condition can help in increasing the rate of weight gain during the intensive phase treatment with $\mathrm{p}$ value $<0.001(\mathrm{p}<0.05)^{16}$, and research conducted by Nagpal et al in 2014 in the City of Amristar in India showed that poor nutritional status was associated with the risk of TB and unfavorable outcomes, the burden of malnutrition was very high but the assessment of nutritional intake was often ignored in clinical practice and in a national TB program, so a counseling is needed regarding nutritional intake for patient with TB with $p$ value of $<0.435(p>0.005) .{ }^{17}$

\section{Conclusions}

Based on the results of the research it can be concluded that there was a significant change in patient nutritional status after the intensive phase treatment of anti tuberculosis drugs. 
Table 1. Baseline characteristics of subjects $(n=84)$

\begin{tabular}{|c|c|}
\hline Characteristic & $\mathrm{n}(\%)$ \\
\hline \multicolumn{2}{|l|}{ Age (years) } \\
\hline $17-25$ & $18(21.4)$ \\
\hline $26-35$ & $21(25.0)$ \\
\hline $36-45$ & $15(17.8)$ \\
\hline $46-55$ & $14(16.7)$ \\
\hline $56-65$ & $12(14.3)$ \\
\hline$>65$ & $4(4.8)$ \\
\hline \multicolumn{2}{|l|}{ Gender } \\
\hline Male & $51(60.7)$ \\
\hline Female & $33(39.3)$ \\
\hline \multicolumn{2}{|c|}{ AFB (Acid-fast bacilli) sputum examination } \\
\hline Positive & $57(67.9)$ \\
\hline Negative & $27(32.1)$ \\
\hline
\end{tabular}

Table 2. Univariate analysis of nutritional status before and after intensive phase treatment

\begin{tabular}{ccc}
\hline & Nutritional status & $\mathrm{n}(\%)$ \\
\hline Before treatment & $61(72.6)$ \\
Abnormal & $23(27.4)$ \\
Normal & \\
After treatment & $50(59.5)$ \\
Abnormal & $34(40.5)$ \\
Normal & \\
\hline
\end{tabular}

Table 3. Bivariate analysis of nutritional status during before and after intensive phase treatment

\begin{tabular}{|c|c|c|c|c|c|}
\hline \multirow{2}{*}{ Nutritional status } & \multicolumn{2}{|c|}{ Abnormal } & \multicolumn{2}{|c|}{ Normal } & \multirow{2}{*}{$\mathrm{p}$} \\
\hline & $\mathrm{n}$ & $\%$ & $\mathrm{n}$ & $\%$ & \\
\hline Before & 61 & 72.6 & 23 & 27.4 & \multirow{2}{*}{$0.001 *$} \\
\hline After & 50 & 59.5 & 34 & 40.5 & \\
\hline
\end{tabular}




\section{Conflict of Interest}

Authors declared no conflict of interest regarding this article.

\section{Open Access}

This article is distributed under the terms of the Creative Commons Attribution 4.0 International Licence

(http://creativecommons.org/licenses/by/4.0/), which permits unrestricted use, distribution, and reproduction in any medium, provided you give appropriate credit to the original author(s) and the source, provide a link to the Creative Commons license, and indicate if changes were made.

\section{References}

1. Nurwitasari A, Wahyuni Cu. Pengaruh Status Gizi Dan Riwayat Kontak Terhadap Kejadian Tuberkulosis Di Kabupaten Jember. Chinese Phys Lett. 2015;3(2):1-12.

2. Putri Wina Asri, Munir S Melati, Christiano E. Gambaran Status Gizi Pada Pasien Tuberkulosis Paru Yang Menjalani Rawat Inap. J Gizi. 2016;3(2):1-16.

3. Suganda Hp, Majdawati A. Hubungan Gambaran Foto Thorax Dengan Hasil Pemeriksaan Sputum BTA Pada Pasien Dengan Klinis Tuberkulosis. 2013;13(1):13-21.AvailableFrom:

Http://Download.Portalgaruda.Org

/Article.Php?Article=417966

$\& \mathrm{Val}=8108 \&$ Title=Hubungan Gambaran Foto Thorax Dengan Hasil Pemeriksaan Sputum Bta Pada Pasien Dengan Klinis Tuberkulosis

4. Kemenkes Ri. Pedoman Nasional Pengendalian Tuberkulosis. Jurnal Kesehatan Masyarakat. Jakarta: Kemenkes Ri; 2011. 1-20 P.

5. Ozer Ek, Goktas Mt, Toker A, Pehlivan S, Bariskaner H, Ugurluoglu C, Et Al. Global Tuberculosis Report. Pharmacological Reports. 2017. 1-277 P.

6. Priyantomo Ep, Sp.P Dr. As, Agustina Arundina S.Gz Mp. Description Of Body Mass Index In Tuberculosis Patient With Anti Tuberculosis Drugs Therapy In Unit Pengobatan Penyakit Paru Paru (Up4) Pontianak. 2014;1-17.
7. Huda I Al, Sari R, Widhiyastuti E. Perbedaan Indeks Massa Tubuh Sebelum Pengobatan Dan Sesudah Pengobatan Pada Pasien Tuberkulosis Paru Di Balai Besar Kesehatan Paru Masyarakat Surakarta. 2013;1-13.

8. Kesehatan M, Indonesia R. Peraturan Menteri Kesehatan Republik Indonesia Nomor 1077/Menkes/Per/V/2011. 2011;1:4-7.

9. Jimmy Lahabama. Hubungan Kepadatan Hunian Rumah Terhadap Penularan Tuberkulosis Paru Di Kota Pontianak. 2013;(1):1-23.

10. Gupta Kb, Gupta R, Atreja A, Verma M, Vishvkarma S. Tuberculosis And Nutrition. 2009;18.

11. Pratomo Ip, Erlina Burhan Vt. Malnutrition And Tuberculosis. 2014;1-8. Available From: Https://Www.Researchgate.Net

/Publication/239949100_Malnutrition_And _ Tuberculosis

12. Dotulong Jfj, Sapulete Mr, Kandou Gd. Hubungan Faktor Risiko Umur, Jenis Kelamin Dan Kepadatan Hunian Dengan Kejadian Penyakit Tb Paru Di Desa Wori Kecamatan Wori. 2012;3:57-65.

13. Nurjannah, Sudana Im. Analisis Pengaruh Fase Pengobatan, Tingkat Depresi Dan Konsumsi Makanan Terhadap Status Gizi Penderita Tuberkulosis (Tb) Paru Di Wilayah Kerja Puskesmas Se- Kecamatan Genuk Kota Semarang. 2017;2(3):215-33.

14. Lestari Ed. Analisis Perubahan Status Gizi Pada Pasien Tuberkulosis Setelah Pengobatan 6 Bulan Di Rs Paru Provinsi Jawa Barat. Inst Pertan Bogor. 2016;5-27.

15. Wokas Jaj, Wongkar Mcp, Surachmanto E. Hubungan Antara Status Gizi, Sputum Bta Dengan Gambaran Rontgen Paru Pada Pasien Tuberkulosis. 2015;3:1-8.

16. Rohini K, Surekha B, P S S, Saxena J, A Mk. Body Weight Gain In Pulmonary Tuberculosis During Chemotherapy. Int J Collab Res Intern Med Public Heal. 2013;5(4):247-54.

17. Nagpal M, Devgun P, Chawla N. A Study On Nutritional Status And Change In Body Mass Index With Treatment Outcome In Smear-Positive Pulmonary Tb Patients On Dots In Amritsar City. Int J Med Sci Public Heal [Internet]. 2015;4(4):454$7 . \quad$ Available From: Http://www.Scopemed.Org/Fulltextpdf.Php?Mno= 173015 